\title{
Evaluation of the ESBLN nerve variations that occur during thyroidectomy
}

\author{
Rashmi R Bhat ${ }^{1}$, Amar D N ${ }^{2 *}$, Satheesha K $S^{3}$ \\ ${ }^{1}$ Associate Professor, ${ }^{2,3}$ Professor, ${ }^{1,3}$ Dept. of Anatomy, ${ }^{2}$ Dept. of General Surgery, Srinivas Institute of Medical Sciences and \\ Research Centre, Mukka, Mangalore, Karnataka, India \\ *Corresponding Author: Amar D N \\ Email: dramardn1984@gmail.com
}

\begin{abstract}
Background and Objective: Anatomy has been the basis if understanding the structure of the human body to the medical fraternity since the time immemorial and still it continues to do so. Though the medical fields has seen a vast change in the understanding of the diseases and the anatomy of the human body, yet, till date anatomical dissection of the human body is probably the best available method that is available to study in detail and see the first hand information regarding the variations of the structures of the human body without causing any harm to the human race.

In the past few years the has been a rise in the number of surgeries that are performed on the thyroid. In today's day even if the goiter is small, the present day generation remove it soon more for cosmetic reasons as compared to the past when people would not bother even it grew to occupy the entire neck.

When we talk about the thyroid, most often importance is paid only to the recurrent laryngeal nerve, but in today's scenario, in a country like India where litigations are on rise towards the medical fraternity has become the important to understand every single anatomical detail even of the minor structures that were once considered as not so important. The superior laryngeal nerve is one such nerve often referred as the neglected nerve as in thyroidectomy this nerve is not often paid as much attention to as its counterpart the recurrent laryngeal nerve. Identification of this nerve at times can be very difficult and a challenging one to the operating surgeon either because of its displacement as a result of gland enlargemet, or due to the fact. Though this nerve has not been given much clinical importance, the morbidy associated with the injury to this neglected nerve at the time of thyroid surgery can be the reason for a significant morbidity. Paralysis of this neglected nerve can cause a very significant disability, especially to those individuals whose occupation depends on the voice. The well-known legendary opera soprano, Amelita Galli-Curci, this neglected nerve at the time of thyroid surgery which is contributed to end her career as an opera singer. This nerve is one of the less studied or the neglected nerve, in view of this we conducted this study.
\end{abstract}

Keywords: Thyroidectomy, Superior laryngeal nerve, Neglected nerve, Paralysis.

\section{Introduction}

Anatomy has been the basis if understanding the structure of the human body to the medical fraternity since the time immemorial and still it continues to do so. Though the medical fields has seen a vast change in the understanding of the diseases and the anatomy of the human body, yet, till date anatomical dissection of the human body is probably the best available method that is available to study in detail and see the first hand information regarding the variations of the structures of the human body without causing any harm to the human race.

In the past few years the has been a rise in the number of surgeries that are performed on the thyroid. In today's day even if the goiter is small, the present day generation remove it soon more for cosmetic reasons as compared to the past when people would not bother even it grew to occupy the entire neck.

When we talk about the thyroid, most often importance is paid only to the recurrent laryngeal nerve, but in today's scenario, in a country like India where litigations are on rise towards the medical fraternity has become the important to understand every single anatomical detail even of the minor structures that were once considered as not so important. The external laryngeal branch of the superior laryngeal nerve is one such nerve often referred as the neglected nerve as in thyroidectomy this nerve is not often paid as much attention to as its counterpart the recurrent laryngeal nerve. 
Identification of this nerve at times can be very difficult and a challenging one to the operating surgeon either because of its displacement as a result of gland enlargement, or due to the fact it has some variation. Most often its rate of identification is also low. Though this nerve has not been given much clinical importance, the morbidly associated with the injury to this neglected nerve at the time of thyroid surgery can be the reason for a significant morbidity. Paralysis of this neglected nerve can cause a very significant disability, especially to those individuals whose occupation depends on the voice. The wellknown legendary opera soprano, Amelita Galli-Curci, this neglected nerve at the time of thyroid surgery which is contributed to end her career as an opera singer. This nerve is one of the less studied or the neglected nerve, in view of this we conducted this study. In view of this we at a medical college teaching hospital at a smart city in India decided to study this neglected nerve, to study its variations and the rate of identification so that it can add to the clinical knowledge of its variation seen.

\section{Materials and Methods}

This study was done in at the department of Anatomy surgery, Srinivas institute of Medical Sciences and research centre, Mukka medical college hospital on 50 cases who underwent who thyroidectomy over a period of 5 years from 2015 to 2019 were included in the study. The rate of identification was done as per the Cernea, Kierner, Friedman and Block variants of the The external laryngeal branch of the superior laryngeal nerve (EBSLN) was considered using standard dissection methods. Any variations of eth antomy were noted

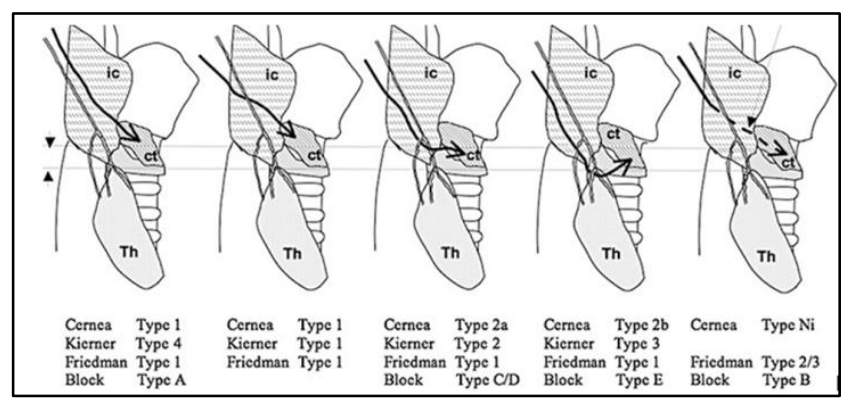

Fig. 1:

\section{Results and analysis}

In only 43 of the 50 nerves ( 25 cadavers, $86 \%$ ) the EBSLN could be identified easily. In 7 patients (20\%) the nerve could not be identified at and further dissection only 6 more could be identified had early branching of the nerve and piercing the larynx in a different area and the nerve was not associated with the thyroid poles. We founds a similar anatomy on both sides in 7 cases $(15 \%)$ in rest of the anatomy was different on the two sides Friedman type 1 was the commonest seen in $32(76 \%$ ) cases, Friedman type 2 in 12 cases $(24 \%)$ and Friedman type 3 in 5 cases (8\%). Of the 1 cases where the nerve was not identified in the first instance, quite far from the thyroid pole and the superior thyroid arterial branches.

\section{Table}

\begin{tabular}{|c|c|c|}
\hline Patients number & Right & Left \\
\hline Patients number 1 & Friedman type 1 & $\begin{array}{c}\text { Friedman } \\
\text { type } 3\end{array}$ \\
\hline Patients number 2 & Friedman type 1 & $\begin{array}{c}\text { Friedman } \\
\text { type } 1\end{array}$ \\
\hline Patients number 3 & Friedman type 1 & $\begin{array}{c}\text { Friedman } \\
\text { type } 3\end{array}$ \\
\hline Patients number 4 & Friedman type 1 & $\begin{array}{c}\text { Friedman } \\
\text { type } 1\end{array}$ \\
\hline Patients number 5 & Friedman type 1 & $\begin{array}{c}\text { Friedman } \\
\text { type } 3\end{array}$ \\
\hline Patients number 6 & Friedman type 1 & $\begin{array}{c}\text { Friedman } \\
\text { type } 3\end{array}$ \\
\hline Patients number 7 & Friedman type 1 & $\begin{array}{c}\text { Friedman } \\
\text { type } 1\end{array}$ \\
\hline Patients number 8 & Friedman type 1 & $\begin{array}{c}\text { Friedman } \\
\text { type } 2\end{array}$ \\
\hline Patients number 9 & Friedman type 1 & $\begin{array}{c}\text { Friedman } \\
\text { type } 1\end{array}$ \\
\hline $\begin{array}{c}\text { Patients number } \\
10\end{array}$ & Friedman type 1 & $\begin{array}{c}\text { Friedman } \\
\text { type } 2\end{array}$ \\
\hline $\begin{array}{c}\text { Patients number } \\
11\end{array}$ & Friedman type 1 & $\begin{array}{c}\text { Friedman } \\
\text { type } 1\end{array}$ \\
\hline $\begin{array}{c}\text { Patients number } \\
12\end{array}$ & Friedman type 1 & $\begin{array}{c}\text { Friedman } \\
\text { type } 2\end{array}$ \\
\hline $\begin{array}{c}\text { Patients number } \\
13\end{array}$ & Friedman type 1 & $\begin{array}{c}\text { Friedman } \\
\text { type } 1\end{array}$ \\
\hline
\end{tabular}




\begin{tabular}{|c|l|c|}
\hline $\begin{array}{c}\text { Patients number } \\
14\end{array}$ & Friedman type 1 & $\begin{array}{c}\text { Friedman } \\
\text { type 2 }\end{array}$ \\
\hline $\begin{array}{c}\text { Patients number } \\
15\end{array}$ & Friedman type 1 & $\begin{array}{c}\text { Friedman } \\
\text { type 2 }\end{array}$ \\
\hline $\begin{array}{c}\text { Patients number } \\
16\end{array}$ & Friedman type 1 & $\begin{array}{c}\text { Friedman } \\
\text { type 1 }\end{array}$ \\
\hline $\begin{array}{c}\text { Patients number } \\
17\end{array}$ & Friedman type 1 & $\begin{array}{c}\text { Friedman } \\
\text { type 2 }\end{array}$ \\
\hline $\begin{array}{c}\text { Patients number } \\
18\end{array}$ & Friedman type 1 & $\begin{array}{c}\text { Friedman } \\
\text { type 2 }\end{array}$ \\
\hline $\begin{array}{c}\text { Patients number } \\
19\end{array}$ & Friedman type 2 & $\begin{array}{c}\text { Friedman } \\
\text { type 1 }\end{array}$ \\
\hline $\begin{array}{c}\text { Patients number } \\
20\end{array}$ & Friedman type 1 & \\
\hline $\begin{array}{c}\text { Patients number } \\
21\end{array}$ & Friedman type 2 & $\begin{array}{c}\text { Friedman } \\
\text { type 1 }\end{array}$ \\
\hline $\begin{array}{c}\text { Patients number } \\
22\end{array}$ & Not identified & $\begin{array}{c}\text { Friedman } \\
\text { type 1 }\end{array}$ \\
\hline $\begin{array}{c}\text { Patients number } \\
23\end{array}$ & Friedman type 1 & Friedman \\
type 2 \\
\hline $\begin{array}{c}\text { Patients number } \\
24\end{array}$ & Friedman type 2 & Friedman \\
type 1 \\
\hline Patients number & Friedman type 2 & $\begin{array}{c}\text { Friedman } \\
\text { type 1 }\end{array}$ \\
\hline
\end{tabular}

\section{Discussion}

In the fundamental anatomy textbooks, the EBSLN is described as passing superficial to inferior constrictor muscle and piercing it to supply cricothyroid muscle. The superior laryngeal nerve is a branch of the vagus nerve. After descending along the side of the pharynx, it divides into two distal branches, the internal and the external laryngeal nerves. The internal laryngeal nerve provides sensory innervation to the glottis and laryngeal vestibule through the thyro-hyoid membrane. The external laryngeal nerve, which is the smaller branch, innervates the cricothyroid muscle and also branches into the pharyngeal plexus and the superior portion of the inferior pharyngeal constrictor ${ }^{1-3}$ The external laryngeal nerve (EBSLN), which is the smaller branch, innervates the cricothyroid muscle and also branches into the pharyngeal plexus and the superior portion of the inferior pharyngeal constrictor 9-14. The cricothyroid muscle tenses the vocal cords and comes into play at frequencies above $150 \mathrm{~Hz}$, so it is particularly involved in producing the high tones of the female voice.

There are several technical approaches designed to preserve the integrity of the EBSLN, including: isolating and individually ligating the superior pole vessels adjacent to the thyroid capsule; identifying the EBSLN prior to securing the vasculature in the same manner; and neuromonitoring of the EBSLN during thyroidectomy. ${ }^{4-6}$ According to Friedman, the EBSLN is at risk in all patients until it has been identified. ${ }^{4}$ Eckley et al. recorded hoarseness, loss of high range, vocal fatigue, breathiness and volume disturbance for the production of loud phonation in 56 patients (30 singers) as a consequence of EBSLN damage, which was confirmed by EMG and laryngostroboscopy; the high coloratura sopranos (like Galli- Curci) seemed to have the worst phonatory problems ${ }^{7}$ In patients with EBSLN damage who were not singers, Robinson et al. found a significant drop in maximum phonation time and range of phonation frequencies; and the percentage of jitter and shimmer, and the noise-toharmonics ratio were abnormally high. ${ }^{7}$ The true incidence of damage to the EBSLN after thyroid surgery is not clear, but its electromyographic incidence ranges from $0 \%$ to $58 \% .^{3}$ In 1992 , Cernea proposed a classification of EBSLN based on the potential risk of injury to the nerve during thyroid surgery according to its relationship with the upper edge of the superior thyroid pole; the author found the highest risk in cases with large goitres. ${ }^{4}$ Aina and Hisham reported that approximately $50 \%$ of the nerves cross below the apex of the thyroid lobe in goitres weighing more than $100 \mathrm{~g}$ (like Galli-Curci's,) where they are at high risk of injury ${ }^{5}$

\section{Conclusion}

We suggest that the surgeon uses the Freidman technique to detect the superior laryngeal nerve in thyroidectomy so that the risk of injury is reduced

\section{Source of Funding}

None.

\section{Conflict of Interest}

None. 


\section{References}

1. Cernea CR, Ferraz AR, Nishio. Surgical anatomy of the external branch of the superior laryngeal nerve. Head Neck 1992;14:380-3.

2. Aina EN, Hisham A. External laryngeal nerve in thyroid surgery: recognition and surgical implications. ANZ J Surg 2001;71:212-4.

3. Aluffi P, Policarpo M, Cherovac C, Post-thyroidectomy superior laryngeal nerve injury. Eur Arch Otorhinolaryngol 2001;258:451-4.

4. Friedman M, LoSavio P, Ibrahim H. Superior laryngeal nerve identification and preservation in thyroidectomy. Arch Otolaryngol Head Neck Surg 2002;128:296-303.

5. Loré JM, Jr, Kokocharov SI, Kaufman S, Thirty-eightyear evaluation of a surgical technique to protect the external branch of the superior laryngeal nerve during thyroidectomy. Ann Otol Rhino Laryngol 1998;107:101522.

6. Moran RE, Castro AF. The superior laryngeal nerve in thyroid surgery. Ann Surg 1951;134:1018

7. Eckley CA, Sataloff RT, Hawkshaw M, Voice range in superior laryngeal nerve paresis and paralysis. $J$ Voice 1998;12:340-48.

How to cite this article: Bhat RR, Amar DN, Satheesha KS. Evaluation of the ESBLN nerve variations that occur during thyroidectomy. Indian J Anat Surg Head Neck Brain 2019;5(3):89-92. 